Vol. 3, No. 2, 2016

UDC 336.74: 339.744.

\author{
B. Ilychok, \\ $\mathrm{PhD}$ in Economics, Associate Professor, \\ O. Trevoho \\ $\mathrm{PhD}$ in Economics, Lecturer, \\ Lviv Polytechnic National University
}

\title{
EXCHANGE RATE OF UKRAINIAN CURRENCY - TRENDS AND POTENTIAL CHANGES
}

\begin{abstract}
The article is devoted to topical issues of increasing hryvnia exchange rate potential. There is presented a description of the main factors causing decrease of the exchange rate, namely: the negative balance of payments, galloping inflation, situational decline in demand for Ukrainian exports and large amounts of currency outflow due to shadow economy agents. Ways of reducing the shadow economy in Ukraine are proposed. The results of the proposed measures would reduce the rate of inflation due to increased state budget revenues; reduce the currency outflow from the country due to decreased domestic oligarchs' demand for luxury goods. Consequently, there will improve the balance of payments, depreciation of hryvnia in its commodity coverage will be minimized, and hryvnia exchange rate will potentially stabilize.
\end{abstract}

Keywords: exchange rate, hryvnia, balance of payments, trade surplus, inflation, shadow economy.

\section{Formulation of the problem}

In open market economies the impact of exchange rate changes on the financial system is very significant. In Ukraine, more than half of residents savings (including savings outside of the financial system) are stored in foreign currency, up to $50 \%$ of residents' debt obligations are formalized in foreign currency. Therefore, research into the issues of stabilizing the exchange rate, which serves as a guide on long-term planning of economic agents' activities, is important and necessary.

\section{Analysis of recent research and publications \\ Exchange rate disbalance that exists in} Ukraine's economy causes the necessity to research its aspects and associated problems with the aim to identify effective levers that can ensure the stability of the national currency. A number of domestic and foreign scientists dedicated their works to investigation of the exchange rate fluctuations and its stabilization, among them being O.Bereslavska, E.Brazhnykova, Ye. Vlasenko, E. Voskresenska, V. Heyets, A.Hoychuk, S. Korablin, I. Kryuchkova, O. Patsenko, V. Shevchuk, A. Shulgin and others.

However, in present conditions of the national economy development there remains relevant the issue of using the most effective regulators, capable of ensuring stabilization of the exchange rate in Ukraine as well as activating both domestic and foreign economic activities of the country.

Most of the publications of domestic scientists on the conditions and problems of the hryvnia exchange rate stabilization mostly deal with monetary measures. At the same time, a significant impact on the dynamics of exchange rate is made by the shadow economy. This article is devoted to the issue of maximum consideration of all the factors affecting the exchange rate and finding ways to minimize their negative impact.

The purpose of the article is to study the status and dynamics of the hryvnia exchange rate fluctuations, to identify the main stages and trends of the currency market and to develop scientific and practical recommendations on the use of levers and tools capable of stabilizing the exchange rate and intensifying socio-economic development of Ukraine.

\section{Presentation of the main material}

On September 1, 2016 the modern Ukrainian national currency - hryvnia - was celebrating its $20^{\text {th }}$ anniversary. During these 20 years the exchange rate has undergone significant changes. 


\section{B. Ilychok, O. Trevoho}

On September 1, 1996, one could buy 62.89 USD for a hundred hryvnias. Twenty years later, on September 1, 2016 you could buy only 3.70 USD for a hundred hryvnias. Thus, during twenty years, the hryvnia has devalued against the US dollar in 17 times. Such significant negative changes require a detailed analysis of their causes and search for the ways to neutralize these factors of change.

The national money becomes currency since its use in international payments. Exchange rate is the price of any currency in terms other currencies. Thus currency is any instrument of payment that can be used in international payments.

The exchange rate of any currency is set in the currency market while trading currencies from different countries.

The currency price, as any other price, is directly dependent on the demand and is in inverse dependency on the currency supply in the foreign exchange market.

All the factors that affect the exchange rate are displayed integrally through the balance of payments. This applies particularly to the trade balance, which reflects the value ratio of exports and imports of the country's goods and services for a certain period of time. The trade balance consists of two parts - revenue and payments. Their comparison creates an export-import balance. Trade balance is the difference between the value of exports and imports. The trade surplus occurs when the value of exports exceeds the value of imports and the trade deficit is observed when the value of imports exceeds the value of exports.

The trade balance of Ukraine in the periods of 1996-1998 and 2005-2015 was deficit, the major reason of the situation being the negative balance of goods. Its dynamics is shown in Fig. 1.

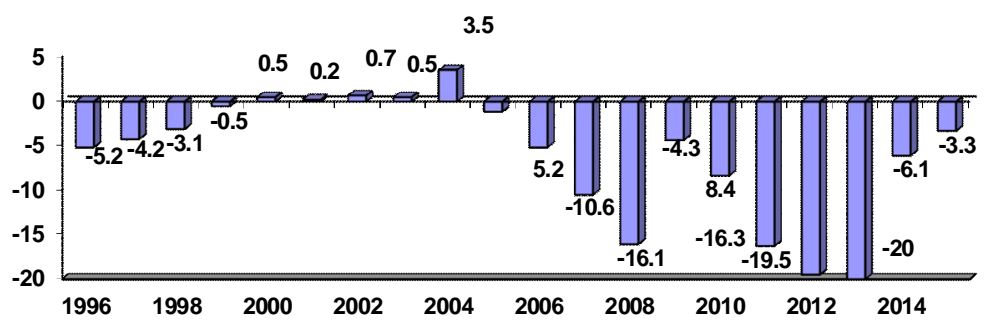

Fig. 1. Ukrainian trade balance of payments, billion USD

\section{Sources: https:/bank.gov.ua/control/uk/publish}

According to the information in Figure 1, during 1996-2015 the overall balance of goods of Ukraine's balance of payments was passive and its deficit reached 118.5 billion USD [1].

This deficit can be financed by: a) the gold and foreign exchange reserves of the state; $b$ ) a net inflow of capital from abroad. To ensure a net inflow of capital from abroad, the government can borrow from foreigners and sell certain amount of own assets to foreigners.

Every year Ukrainian emigrants transfer about 7.5 billion USD [2]. Over the past 20 years the total amount of currency transfers amounted to about 150 billion USD. These transfers are main funds for supporting everyday life, buying housing, educating children of emigrant families.

A very important factor of stabilizing the exchange rate of hryvnia is that the net inflow of capital from abroad in the form of currency earnings from Ukrainian emigrants during 1996-2015 actually covers the negative trade balance.

The current situation with earnings and expenditures of foreign exchange funds by Ukraine affected the amount of gold and foreign exchange reserves as well as the amount of borrowings (debt).

The dynamics of gold and foreign exchange reserves of the National Bank of Ukraine (NBU) is shown in Fig. 2.

The most favorable years for gold and foreign exchange reserves of the NBU were 20032010. During this period foreign exchange reserves increased from 3.4 billion USD at the beginning of 2003 to 34.6 billion USD at the end of 2010, having increased tenfold. [3] 


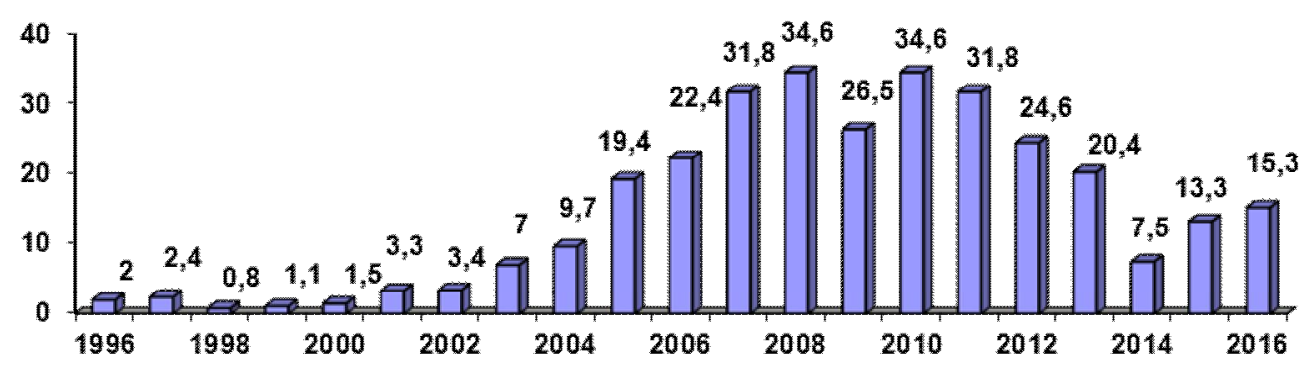

Fig. 2. Dynamics of gold and foreign exchange reserves of the $N B U$ for 1996-2016, billion USD, at the end of the year

Sources: https:/bank.gov.ua/control/uk/publish

According to the information in Fig. 3, during 2005-2013 the national debt of Ukraine was growing. The problem of the amount of public debt in Ukraine has become particularly acute since the beginning of world financial crisis in autumn of 2008.

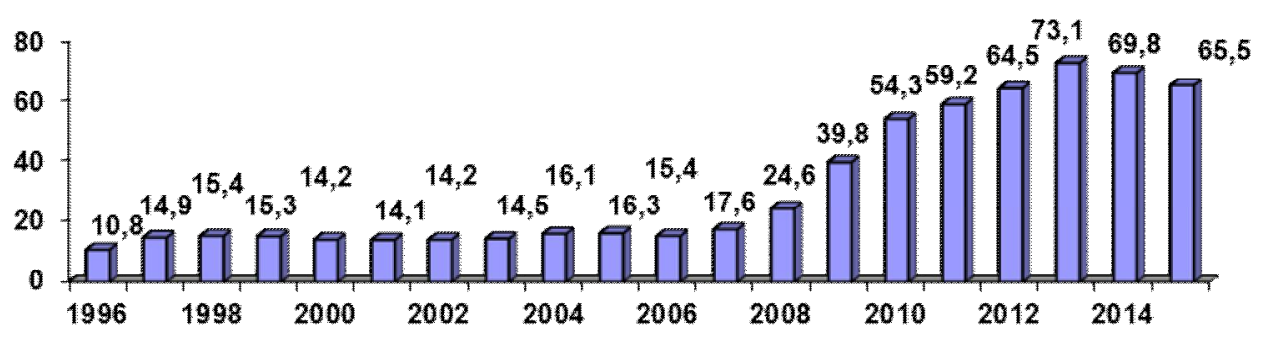

Fig. 3. The public debt of Ukraine during 1996-2015 years, billion USD.

Sources: http://www.minfin.gov.ua/news/view/statystychni-materialy-shchodo-derzhavnoho-ta-harantovanohoderzhavoiu-borhu-ukrainy|

There are several reasons for the rapid increase in government debt in 2009-2010. Firstly, the government conducted an active stabilization policy including the banking system rescue (experience of South Korea and Thailand in 19971998, as well as Latin America from the early 1980s) Actually part of the private debt was replaced by the state debt. Secondly, the government borrowings, by their nature, are not long-term investments, so they do not contribute to sustainable long-term economic growth and debt repayment; more so, they even increase the debt burden. Thirdly, a great part of Ukrainian capital expenditures have no economic justification, there is no mechanism of public investments regulation, transparency of their use, monitoring their efficiency [5].

At the end of 2013 the national debt of Ukraine reached 73.1 billion USD. The public debt of Ukraine has been reducing since 2014. In particular, in 2014 the figure decreased by 3.3 billion USD and by the end of the year was 69.8 billion USD. During 2015 the national debt of Ukraine decreased by 4.3 billion USD and by the end of 2015 amounted to 65.5 billion USD [4].

This negative trade balance of payments had an adverse effect on the exchange rate of Ukrainian currency. After all, between the trade balance and exchange rate there exists inverse relationship. With the deterioration of the trade balance (increasing negative balance), the country spent more money abroad than received it from the sale of its products. For example, in 2012 Ukraine bought 19.5 billion USD worth foreign goods that exceeds foreign sales. In 2013 negativetrade balance increased to 20 billion USD. Thus during just two years 2012-2013 due to the negative trade balance Ukraine "depleted" by 39.5 billion USD [1]. This created reasonable grounds for a potential 


\section{B. Ilychok, O. Trevoho}

reduction of exchange rate in the short term. Since the demand for foreign currency needed to buy imports increased on the foreign exchange market, the currency supply increased as a consequence. This, in turn, contributed to the potential reduction of the hryvnia exchange rate.

Active or passive trade balance characterizes the country's competitiveness on the global market. Given the overall passive trade balance of Ukraine, the competitiveness of domestic products on the world market is insufficient. Domestic scientists, including M. L. Danylovych-Kropyvnytska are paying special attention to this problem and the ways to solve it in their studies [6].

An important factor of the negative impact on the exchange rate in Ukraine is inflation.
According to the information in Fig. 5, in Ukraine during the studied period of time there was taking place a significant inflation process [7, p.31]. This led to depreciation of the purchasing power of the national currency and as a result made a potentially negative impact on the exchange rate of hryvnia.

In view of the above, holders of savings in the national currency were trying to convert them into a more stable (hard) currency, such as USD. This contributed to an even greater potential depreciation of the national currency against the US dollar.

Information about the dynamics of the hryvnia exchange rate against the USD during 1996-2015 is shown in Fig. 6.

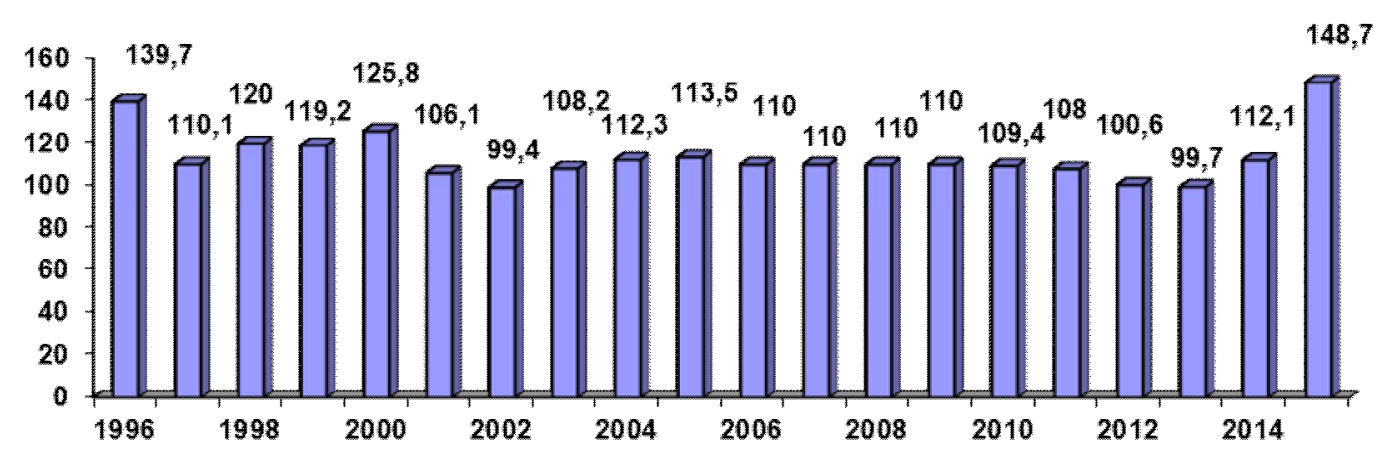

Fig. 5. Inflation (CPI) in Ukraine in 1996-2015, in \%

Sources: Statistical Yearbook of Ukraine for 2015. State Statistics Service of Ukraine. - Kyiv, 2016. - P. 31.

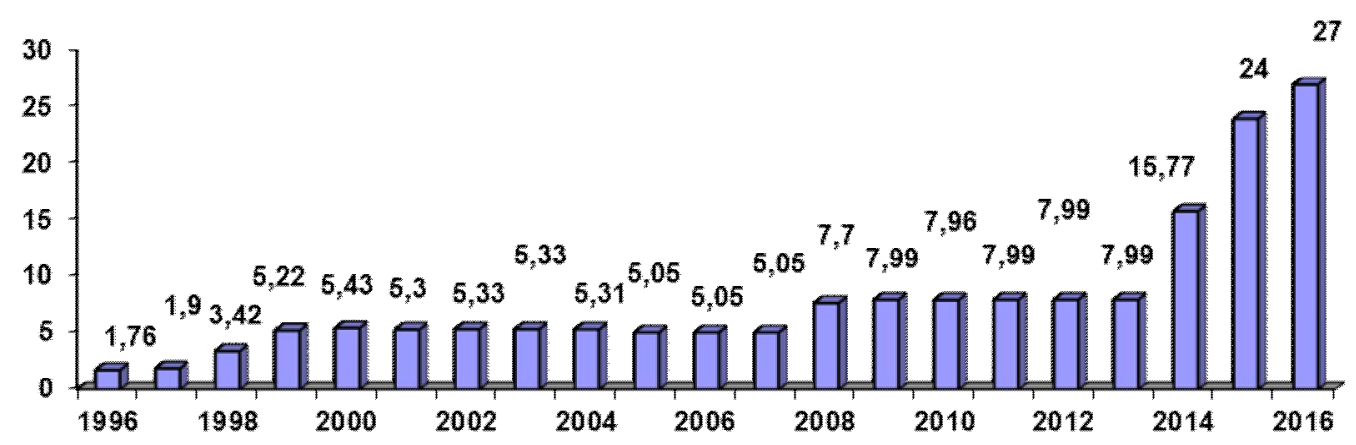

Fig. 6. Dynamics of hryvnia exchange rate against the US dollar during 1996-2016, at the end of the year

In the studied period of time exchange rate was not correlated annually according to the level of hryvnia purchasing power. For example, during 2005-2007, the purchasing power of the national currency due to inflation decreased by $35.3 \%$ $(113.5 \times 1.1 \times 1.1=135.3)$. At the same time (according to the monetary strategy of the government and the NBU) exchange rate in 20052007 remained stable 5.05 UAH / USD [8]. This disparity couldn't exist in the long run.

During the period of 1996-2015 decreasing of hryvnia exchange rate was not going smoothly, but 


\section{Exchange Rate of Ukrainian Currency - Trends and Potential Changes}

abruptly. Over the past twenty years there have been three significant abrupt falls in the exchange rate.

The first - from August 1998 to December 1999, when in the course of "Asian" crisis deployment, the exchange rate of hryvnia against US dollar decreased from 1.9 UAH/ USD to 5.22 $\mathrm{UAH} / \mathrm{USD}$, that is in 2.75 times.

The second - from August 2008 to December 2008, when in the course of the "world financial" crisis the exchange rate of hryvnia against the US dollar fell from 5.05 UAH/ USD to 7.70 UAH / USD, that is by $52.5 \%$.

The third - from March 2014 to December 2015, when in the process of deploying the "Russian Spring" and the Russian occupation of Ukrainian territory of the Crimea and Donbas, the exchange rate of hryvnia against the US dollar fell from 7.99 UAH / USD to $24.00 \mathrm{UAH} / \mathrm{USD}$, that is in 3.0 times.

All the three stages of exchange rate decrease directly related to a sharp decline in demand for Ukrainian products in foreign markets. The consequence of this situation was a sharp increase in the negative trade balance. For example, in 2008 the negative trade balance reached 16.1 billion USD. This led to: a) reduction of gold and foreign exchange reserves, for example, in 2008-2009 by 8.1 billion USD; b) reduction of exchange rate, including the fall of 2008 from 5.05 UAH / USD to 7.7 UAH / USD. As a consequence, the volume of external debt of Ukraine increased. For example, with 26.4 billion USD in 2008 , it increased to 39.8 billion USD in 2009 , totally it increases by 13.4 billion.

A significant reduction of exchange rate in the period of 2014-2015 was not only due to the war with Russia and against the last occupation of Ukrainian territory in the Crimea and Donbas. This is the actual limits of the Russian market for Ukrainian goods, as evidenced by data in Table 1 .

In 1996 the Russian market accounted for $38.7 \%$ of exports from Ukraine. In 2015 it was only $12.7 \%$. The share of Ukraine's exports of goods to the Russian market during 1996-2015 decreased by 26.0 percentage points [7, p. 399-401].

Instead, domestic exporters quickly discover other promising markets. For example, the share of exports from Ukraine to Egypt during the analyzed period increased by 4.8 percentage points; to China - by $4.6 \%$ percentage points; to Turkey - by $4.5 \%$ percentage points [7, p. 399-401].

The structure of Ukrainian exports to other countries in 1996-2015

Table 1

\begin{tabular}{|c|l|c|c|c|c|c|}
\hline \multirow{2}{*}{ No. Countries } & \multirow{2}{*}{$\begin{array}{c}\text { Volumes } \\
\text { (billion USD) }\end{array}$} & \multicolumn{2}{c|}{ Structure, \% } & $\begin{array}{c}\text { Deviation in } \\
\text { structure } \\
\text { \% points }\end{array}$ \\
\cline { 3 - 6 } & & 1996 & 2015 & 1996 & 2015 & -2.7 \\
\hline 1 & Belorussia & 722.5 & 870.7 & 5.0 & 2.3 & $+\mathbf{4 . 8}$ \\
\hline 2 & Egypt & 96.8 & 2079.8 & 0.7 & 5.5 & +3.2 \\
\hline 3 & India & 82.3 & 1444.1 & 0.6 & 3.8 & +0.4 \\
\hline 4 & Iran, Islam Republic & 116.5 & 472.5 & 0.8 & 1.2 & +1.4 \\
\hline 5 & Iraq & 0.00 & 533.6 & 0.0 & 1.4 & $+\mathbf{4 . 6}$ \\
\hline 6 & Spain & 90.2 & 1979.8 & 0.6 & 5.2 & +1.3 \\
\hline 7 & Kazakhstan & 90.9 & 712.7 & 0.6 & 1.9 & +1.0 \\
\hline 8 & China & 768.1 & 2399.1 & 5.3 & 6.3 & -0.3 \\
\hline 9 & Moldova & 237.8 & 524.3 & 1.7 & 1.4 & +1.7 \\
\hline 10 & Netherlands & 99.7 & 905.7 & 0.7 & 2.4 & +0.6 \\
\hline 11 & Germany & 421.9 & 1328.7 & 2.9 & 3.5 & +2.7 \\
\hline 12 & Poland & 362.7 & 1977.3 & 2.5 & 5.2 & -26.0 \\
\hline 13 & Russia & 5577.4 & 4827.7 & 38.7 & 12.7 & +0.4 \\
\hline 14 & Rumania & 157.3 & 569.9 & 1.1 & 1.5 & +1.8 \\
\hline 15 & Saudi Arabia & 28.1 & 761.6 & 0.2 & 2.0 & -0.4 \\
\hline 16 & Slovakia & 230.6 & 468.8 & 1.6 & 1.2 & +4.5 \\
\hline 17 & Turkey & 408.7 & 2771.8 & 2.8 & 7.3 & -0.2 \\
\hline 18 & Hungary & 371.6 & 909.7 & 2.6 & 2.4 & +0.5 \\
\hline 19 & France & 111.1 & 497.9 & 0.8 & 1.3 & +0.4 \\
\hline 20 & Check Republic & 143.0 & 541.0 & 1.0 & 1.4 & X \\
\hline 21 & Total export & 14400.8 & 38127.1 & 100.0 & 100.0 & \\
\hline
\end{tabular}

Sources: Statistical Yearbook of Ukraine for 2015. State Statistics Service of Ukraine. - K., 2016. - P. 399-401). 


\section{B. Ilychok, O. Trevoho}

A considerable damage to hryvnia exchange rate is inflicted by two major problems in state governance of Ukraine:

- total tax avoidance by large (oligarchic) corporations;

- massive theft of state budget resources.

According to the information of the Ministry of Economic Development and Trade of Ukraine, the level of shadow economy in Ukraine in 2015 amounted to about $40 \%$ [9]. Considering that in 2015 Ukraine's GDP totaled 1,979.5 billion UAH, the net profits of the shadow sector in 2015 amounted to about 790 billion UAH (1979,5 billion $\mathrm{UAH} \times 0.40=790$ billion UAH). 500 billion $\mathrm{UAH}$ of this amount depends on the corporate sector, owned by oligarchs.

Along with the above, in Ukraine the scale of avoiding income tax payments by fraud through offshore companies is enormous. These transactions take place "in accordance with applicable law" because the list of offshore zones is approved by the Cabinet of Ministers of Ukraine [10].

For this situation, the Ministry of Economic Development and Trade of Ukraine points that the current situation of tax avoidance is caused by "significant tax burden on the corporate sector against the backdrop of the high cost of credit resources and the unfavorable external economic conditions in key commodity markets". [9] The Ministry says nothing about ineffective work of fiscal services to reduce the amount of shadow economy.

The superprofits obtained through offshore manipulations partially return to Ukraine by foreign investment. Particularly, by January 1, 2015 the total amount of direct foreign investments in Ukraine was 45.7 billion USD, $30 \%$ of which (13.7 billion USD) came from Cyprus [7, p. 515]. No other country in the world has invested in Ukraine as foreign direct investments as much as a small island state of Cyprus. For example, by January 1, 2015 Germany had invested in Ukraine only 5.4 billion USD [7, p. 515], that is 2.5 times less than Cyprus.

Unfortunately, Ukrainian government officials do not lag behind the oligarchs. The scale of abuse by government officials in Ukraine is well-known. The evidence provided to the AntiCorruption Bureau in 9/12/2016 by oligarch I.Kolomoyskyi, who accused top management of the country in extortion and receiving a bribe from him,110 million UAH [11].
Ukrainian MPs, having official incomes four times lower than the incomes of the Polish Sejm members, declared property, which is on average five times larger than the wealth of the Polish Sejm members. A similar situation is observed with incomes of the top management of the Cabinet of Ministers and other government branches in Ukraine [12]. No member of the Polish Sejm has income that would allow him to buy the car of VIP class. [12]

As we have noted above, an important factor supporting hryvnia exchange rate is the inflow of currency from abroad from Ukrainian workersemigrants. But most of this money is accumulated by the leaders of the shadow sector and then withdrawn from the country. In 2015, during very difficult time for Ukraine, there were imported VIP class cars in the amount of about one billion US dollars. There are hundreds of villas and yachts owned by top officials of Ukraine abroad. On the acquisition and maintenance of these luxury "attributes" there were spent tens of billions of US dollars. This has definitely a negative impact on the trade balance of the state.

Due to the current situation, the state does not fulfill the redistributive social function. The wealth, created by the work of the society members, is not the property of the Ukrainian people and is concentrated in the hands of oligarchic clans. Incomes, obtained through the informal sector, are mostly converted into hard currency. This increases the foreign currency demand in the foreign exchange market and the negative impact on the hryvnia exchange rate.

Summarizing the above, there is reason to believe that during 1996-2015 the main negative factors influencing the exchange rate of hryvnia were:

a) passive trade balance of payments, which in total reached 120.0 billion USD;

b) a significant rate of inflation;

c) huge amounts of shadow economy in the country, resulting in the flow-out of substantial amounts of currency abroad.

To eliminate these problems, the Ukrainian society, non-governmental organizations should intensify the work of state authorities in two strategic areas:

1) ensuring real publicity in control over budget funds;

2) restricting the volume of offshore and shady frauds of big corporations. 


\section{Exchange Rate of Ukrainian Currency - Trends and Potential Changes}

These tasks have some specifics in their implementation. The first problem requires immediate publicity in control over budget funds and real punishment for guilty government officials of sabotaging these changes in parliament and getting shady income.

Among the three branches of the state power the emphasis should be placed on the judicial reform. At present it is just this branch of power that is pushing the country into the abyss because of frankly immoral and illegal court decisions legitimize raidering, minimize liability for criminal offenses. $60 \%$ of the current judges as a result of judicial reforms should be dismissed. The relevance of judicial reform and the need for an immediate initiation of the anti-corruption courts in Ukraine are stressed by most influential organizations, including the leaders of Ukrainian churches, artists [13], MEPs and others.

Solving the second problem must be based on the system of gradual changes in the State Fiscal Service. Twenty years ago, one of the authors of the given research suggested that UFS need systematic approach, able to significantly and gradually reduce the level of shadow economy in the country $[14,17]$. This approach can be applied even today to the gradual restriction of the shadow frauds of large corporation owners. For this, the use of the system main evaluation criterion should be the profitability of operating activities of enterprises and corporations to compare it to the same indicator on average according to the type of activity of these corporations [15, p. 94-97].Those enterprises whose profitability ratios of operating activities will be lower than the average for this type of activity will have to be the objects of attention for Fiscal Service. If Antimonopoly Committee of Ukraine and other controlling services are involved in this process, management of the state will ensure that these segments of the market are working on the basis of competition; it will also significantly limit the volume of operations of offshore trading houses, established at oligarchs' corporations.

Due to increasing profitability ratios of the operational activities of the investigated enterprises there will increase the average profitability ratios of the operational activity by the type of their activity. As a consequence, other companies may emerge where these indicators will be shown below average. Now these enterprises-outsiders in terms of the profitability of operational activities will become the objects of inspection. And this process should go on continuously.

Indeed, the current situation in the economy, where the bulk of the oligarchs' corporate sector works with operational activities profitability of 2$4 \%$ [7, p. 480] is frankly laughable, if not sad.

The main contribution to this process should be made by Ukrainian parliament. For example, after "Panama scandal" Great Britain is planning to introduce criminal liability for the companies that allow their employees to help others avoid paying taxes [16].

\section{Conclusions and perspectives for further research}

The research provides characteristics of the main factors that during 1996-2015 negatively affected the hryvnia exchange rate and its dynamics. Attention was focused on the study of the negative impact of the shadow economy on the hryvnia exchange rate and the ways of reducing the shadow economy in Ukraine.

After implementing the proposed measures the revenues of the state must increase. This should positively affect the NBU monetary policy due to reducing the rate of inflation in the national economy. By reduction of oligarchs' shadow incomes it will be possible to decrease the outflow of currency abroad, in particular, due to lowering oligarchs' demand for luxury goods.

As a result, the balance of payments will be improved, the process of inflationary devaluation of the hryvnia will be minimized, the national economy will receive additional incentives for economic growth through the effective increase in aggregate demand, and domestic market will become more stable by reducing dependence on external demand; gold and foreign exchange reserves will increase, the national debt will decrease and the exchange rate will become more stable.

Further research should take into account the fact that the current systems of exchange rates are directly tied to the competitiveness of national economies. Accordingly, to increase the potential of the hryvnia exchange rate stability one should focus on research into the factors of Ukraine's global competitiveness and systems continuous improvement of the factors that contribute to its increase. 


\section{B. Ilychok, O. Trevoho}

\section{References}

1. The balance of payments of Ukraine. [Electronic resource]. - Access: https: /bank.gov.ua/control/uk/publish/.

2. Migrant workers in Ukraine have listed more than 7.5 billion US dollars. - [Electronic resource]. - Access: www/radiosvoboda.org/al 27075873.html.

3. Foreign exchange reserves of the NBU. [Electronic resource]. Access: insider / com.ua / spravochnik.

4. Statistical information on debt. [Electronic resource]. - Access: http: //www.minfin.gov. ua/news/view/statystychni-materialy-shchododerzhavnoho-ta-harantovanoho-derzhavoiu-borhuukrainy.

5. Linnik O.A. Formation of external state debt of Ukraine in 2010-2014: Causes and consequences I O. A. Linnik // Regional Economics. - 2015. No. 1. - P. 104-114.

6. D. Kropivnitskogo-ML Improving the competitiveness of Ukraine's economy-ness in the paradigm of productivity // Herald "Lviv Polytechnic" "Logistics". - No. 690. - Lviv: "Lviv Polytechnic", 2010. - P. 580-586.

7. Statistical Yearbook of Ukraine for 2015. State Statistics Service of Ukraine. - Kyiv, 2016. - 574 p.

8. Currency Bank. [Electronic resource]. - Access: finance.i.ua/nbu/.

9. The level of the shadow economy Ukraine has decreased to $40 \%$ of GDP. Ministry of Economic Development and Trade of Ukraine. [Electronic resource]. - Access: http://www. epravda. com.ua/news/2016/07/4/597966/.

10. CMU of 16 September 2015, the. Number 977-r "On approving the list of states (areas) that meet the criteria established by subparagraph 39.2.1.2 subparagraph 39.2.1 paragraph 39.2 of Article 39 of the Tax Code of Ukraine." [Electronic resource]. - Access: http://kodeksy.com.ual norm_akt/source-KMY

11. Bribe of $\$ 110$ million. [Electronic resource]. Access: $\quad$ glavcom.ua/publication/habarnallomilyoniv-kolomoyskiy-nadavantikorupciynomu-byuro-kompromat.

12. Mateusz Balyas. Polish MPs are poor as church mice, compared with Ukrainian colleagues. School management Ukrainian Catholic University. [Electronic resource]. - Access: http://spm.ucu.edu.ua/2016/11/03/polskideputaty-bidni-yak-tserkovni-myshiporivnyuyuchy-z-ukrayinskymy-kolegamy/.

13. Vakarchuk handed Poroshenko requirement for anti-corruption courts. [Electronic resource]. Access: http://www.pravda.com.ua/news

14. Ilychok B. I. The shadow economy in Ukraine and ways of its solution // Regional Economics. 1997. - No. 3. - S. 134-142.

15. Ilychok B. I. Analysis of business entities in commodity markets [teach. guidances. for students. universities] / B. I. Ilychok: Lviv "Lviv Polytechnic", 2016. - 171 p.

16. Deofshoring Berlin calls for an international register of companies. [Electronic resource]. Access: http://www.dw.com/uk/19177961.

17. Trevoho O. State, prospects and problems of development of domestic engineering management during the exit from the global economic crisis / O. Trevoho, M. Shvetsov // Bulletin Nat. Univ "Lviv Polytechnic" "Management and Entrepreneurship in Ukraine: stages of formation and development problems" No. 778. - Lviv: Lviv Polytechnic Publishing House. -2013. 